\title{
Israel dan Konflik Sosial: Kajian Sosio-Historis Terhadap 1 Raja-Raja 12:1-19
}

\author{
Osian Orjumi Moru ${ }^{1)^{*}}$ \\ 1) Institut Agama Kristen Negeri Kupang, Indonesia \\ *) E-mail: osianmoru@gmail.com
}

Diterima: 02 Nov. 2020

Direvisi: 04 Juni 2021

Disetujui: 10 Juni 2021

\begin{abstract}
Abstrak
Konflik sosial merupakan hal yang wajar dalam suatu proses sosial. Konflik sosial merupakan ciri khas yang menunjukan bahwa suatu masyarakat sedang mengalami proses perubahan secara dinamis. Konflik sosial yang ditata secara baik akan menghasilkan dampak yang baik, sebaliknya jika tidak maka konflik akan berakhir dengan kekerasan dan perpecahan. Hal inilah yang ditunjukan dalam kisah konflik yang tercatat dalam 1 Raja-raja 12:1-19. Kisah tersebut merupakan gambaran utuh dari peristiwa konflik yang tidak tertata dengan baik. Akibatnya, terjadilah kekerasan dan revolusi sosial yang berdampak luas bagi seluruh masyarakat Israel. Berdasarkan konsep dasar tersebut, maka tulisan ini bertujuan untuk memberikan penjelasan yang komprehensif tentang sebab, bentuk dan akibat dari peristiwa konflik dalam kisah 1 Raja-raja 12:1-19. Tulisan ini juga bertujuan untuk menjelasan tentang relevansi kekinian yang dapat dipelajari dari kisah konflik sosial dalam 1 Rajaraja 12:1-19. Pendekatan yang digunakan dalam penelitian ini adalah pendekatan sosio-historis melalui studi kepustakaan untuk menghasilkan suatu kesimpulan penelitian terhadap kisah 1 Raja-raja 12:1-19. Hasil penelitian terhadap topik "Israel dan konflik sosial" menunjukan bahwa tindakan penindasan, ekploitasi dan diskriminasi diduga telah menjadi faktor utama penyebab terjadinya konflik sosial dan perpecahan masyarakat Israel.
\end{abstract}

Kata-Kata Kunci: Israel; Konflik Sosial; Perpecahan. 


\section{Abstract}

Social conflict is a natural thing in a social process. Social conflict is a characteristic that shows that a society is undergoing a dynamic process of change. A well-managed social conflict will have a good impact, otherwise it will end in violence and division. This is what is shown in the story of conflict which is recorded in 1 Kings 12:1-19. The story is a complete picture of the incidents of conflict that are not well ordered. As a result, there was violence and a social revolution that had far-reaching implications for Israel society. Based on that basic concept, this paper aims to provide a comprehensive explanation of causes, forms and effects of the conflict events in the story of 1 Kings 12:1-19. This paper also aims to explain the current relevance of social conflict which can be learned from the story of 1 Kings 12: 1- 19. The approach used in this research is socio-historical approach through literature study to produce a research conclusion on the story of 1 kings 12:1-19. The conclusion of the research results on the topic "Israel and social conflict" shows that acts of oppression, exploitation and discrimination are thought to have been the main factors causing social conflicts and the split of Israel society.

Keywords: Israel; Social Conflict; Split.

\section{Pendahuluan}

Pada dasarnya setiap masyarakat yang bersifat dinamis merupakan komunitas sosial yang terus berproses dengan perubahan. Perubahan masyarakat dapat mengenai berbagai aspek, nilai dan dimensi dalam suatu proses sosial. Berbagai bentuk perubahan dapat membantu masyarakat mengalami berbagai pembaharuan dan perkembangan kehidupan sosial. Menurut Wilbert Moore, perubahan sosial masyarakat adalah perubahan penting dari bentuk struktur sosial masyarakat. Sedangkan struktur sosial sendiri merupakan berbagai pola perilaku dan interaksi sosial individu dalam masyarakat. ${ }^{1}$ Sejalan dengan hal tersebut, Samuel Koening memahami proses perubahan sosial sebagai suatu pola yang menunjuk kepada modifikasi-modifikasi yang terjadi pada kehidupan manusia. ${ }^{2}$ Dengan demikian, setiap perubahan sosial masyarakat dapat dikatakan memiliki cakupan yang beragam dan melibatkan berbagai kekuatan penting pada struktur sosial masyarakat. 2001), 4 .

${ }^{1}$ Roberth H. Lauer, Perspektif Tentang Perubahan Sosial (Jakarta: PT Rineka Cipta,

${ }^{2}$ Samuel Koenig, Mand and Society, the Basic Teaching of Sociology (New York: Barners \& Noble Inc, 1957), 279. 
Proses perubahan sosial masyarakat adalah suatu bentuk gejala alamiah yang menunjukan eksistensi masyarakat dalam hubungannya dengan berbagai konteks kehidupan. Masyarakat menjadi subjek utama yang mengkonstruksi dimensi-dimensi kehidupan individu sehingga menghasilkan berbagai perubahan sosial. Perubahan-perubahan sosial pada suatu masyarakat dapat hadir dalam berbagai dimensi, bentuk dan kondisi. Menurut Robert H. Lauer, wujud mekanisme sosial yang mendorong terjadinya perubahan pada komunitas masyarakat adalah kondisi konflik. ${ }^{3}$

Konflik menjadi persoalan penting yang berperan dalam pembentukan dan pengembangan karakteristik suatu masyarakat. Konflik merupakan suatu kenyataan hidup, tidak terhindarkan dan sering bersifat kreatif. ${ }^{4}$ Konflik dapat mendorong terbentuknya ikatan persatuan masyarakat yang semakin kokoh, namun juga dapat mempercepat terjadinya perpecahan dan diferensiasi sosial yang luas. Konflik yang tidak tertata secara baik akan berujung kepada pembentukan karakteristik masyarakat yang terpecah dan terpisah dari ikatan solidaritas mekanisnya. Kondisi konflik tersebut juga dapat mendorong dan menciptakan terjadinya pembaharuan masyarakat secara tak seimbang.

Dampak destruktif dari konflik semacam itu, muncul secara jelas dalam kisah 1 Raja-raja 12:1-19. Dalam cerita tersebut digambarkan tentang suatu peristiwa konflik yang berujung kepada terjadinya revolusi sosial yang memaksa terbentuknya deferensiasi sosial secara luas antara suku-suku di Palestina. Teks 1 Raja-raja 12:1-19 memberi gambaran utuh tentang asal-muasal terbentuknya konflik sosial di Israel pada sekitar tahun 931/930 sM.

Peristiwa konflik pada bangsa Israel telah memunculkan berbagai perdebatan dan pertanyaan kontroversial diseputaran sebab terjadinya konflik tersebut. Perdebatan yang muncul merupakan dua tarikan ide yang melihat persoalan konflik di Israel sebagai wujud proses sosial yang bersifat multidimensional. Gottwald menyebut penyebab terjadinya konflik di Israel antara tahun 931/930 sM sebagai the dual causality principle. ${ }^{5}$ Gottwald dalam tulisannya menjelaskan tentang dua alasan yang menjadi penyebab terjadinya perpisahan kerajaan Israel Bersatu antara tahun 931/930 sM yakni alasan

${ }^{3}$ Lauer, Perspektif Tentang Perubahan Sosial, 287.

${ }^{4}$ Mustamin, "Studi Konflik Sosial Di Desa Bugis Dan Parangina Kecamatan Sape Kabupaten Bima Tahun 2014," Jurnal Ilmiah Mandala Education 2, no. 2 (2016): 185-205.

${ }^{5}$ Norman K. Gottwald, The Politics of Ancient Israel (Louisville-Kentucky: Westminster John Press, 2001), 252. 
spiritual yang tercatat dalam 1 Raja-raja 11:1-13 dan alasan riil yang tercatat dalam kisah 1 Raja-raja 12:1-19.

Dua alasan tersebut secara teknis memiliki sudut pandang yang berbeda. Akibatnya, telah memunculkan berbagai pertanyaan dan tafsiran yang beragam. Atas dasar persoalan tersebut, maka artikel ini dirancang untuk menjawab pertanyaan tentang bagaimana kondisi riil masyarakat Israel pada masa terjadinya konflik sosial seperti yang dicatat dalam 1 Raja-raja 12:1-19. Menyangkut perihal diatas, penulisan artikel ini bertujuan untuk menjelaskan secara eksplisit tentang kondisi sosio-historis penyebab terjadinya konflik dan perpecahan masyarakat kerajaan Israel Bersatu seperti yang dicatat dalam 1 Raja-raja 12:1-19. Penjelasan artikel ini menjadi penting, sebab mampu menyajikan gambaran sejarah yang bersifat holistik, komprehensif, dan kontekstual atas peristiwa konflik yang pernah terjadi di Israel pada tahun 931/930 sM.

Secara struktural, pembahasan artikel ini dimulai dari suatu penjelasan tentang keterkaitan antara konsep konflik dengan konsep perubahan sosial. Pembahasan tersebut kemudian dilanjutkan dengan penjelasan yang bersifat holistik tentang peristiwa konflik sosial antara suku-suku Israel seperti yang tercatat dalam kisah 1 Raja-raja 12:1-19. Artikel ini kemudian diakhiri dengan upaya untuk mencari suatu relevansi kekinian atau makna konteksual dari peristiwa konflik sosial yang terjadi di Israel dalam kerangka masyarakat modern saat ini.

\section{Metode Penelitian}

Metode penelitian yang digunakan pada tulisan ini adalah metode kualitatif dengan pendekatan sosio-historis. Metode kualitatif dipahami sebagai suatu metode yang menggambarkan objek penelitian secara deskriptif dengan menggunakan data hasil penelitian yang bersifat induktif. Metode ini menggunakan berbagai sumber data mendalam yang mengandung makna. ${ }^{6}$ Sedangkankan jenis pendekatan yang dipergunakan pada tulisan ini adalah pendekatan sosio-historis ${ }^{7}$ melalui studi kepustakaan. ${ }^{8}$ Berpikir dengan cara

\footnotetext{
${ }^{6}$ Mulharnetti Syas, "Konstruksi Realitas Pemberitaan Tentang Konflik IndonesiaMalaysia Di Surat Kabar Media Indonesia," Jurnal Ilmu Komunikasi 13, no. 2 (2015): 124-134.

7 Nurul Djazimah, "Pendekatan Sosio-Historis: Alternatif dalam Memahami Perkembangan Ilmu Kalam”, Jurnal Ilmiah Ilmu Ushuluddin, Vol. 11, No. 1 (2012): 43-60, http://jurnal.uin-antasari.ac.id/index.php/ushuluddin/article/view/732/597.
} 
pendekatan sosio-historis berarti suatu usaha untuk memahami teks dengan menariknya ke arah fakta-fakta sejarah dan sosial suatu masyarakat dimana teks tersebut lahir dan berkembang. Dalam artikel ini, analisis sosio-historis dipakai untuk menjelaskan runtut peristiwa dan data-data sejarah tentang latarbelakang kondisi, sebab dan akibat konflik sosial dalam kisah 1 Raja-raja 12:1-19. Berbagai informasi sejarah tentang peristiwa konflik pada kisah 1 Raja-raja 12:1-19 kemudian dianalisis secara mendalam sehingga menghasilkan suatu kesimpulan hasil penelitian yang bersifat sahih dan memiliki relevansi bagi kehidupan masyarakat pada masa kini.

\section{Pembahasan dan Hasil}

\section{Konflik dan Perubahan Sosial Masyarakat}

Masyarakat merupakan komunitas sosial yang secara teoritis dan teknis akan terus bergerak secara dinamis sehingga akan mengalami berbagai perubahan sosial. Perubahan sosial masyarakat adalah elemen penting yang mengkonstruksi wajah suatu komunitas masyarakat. Pada akhirnya hal ini akan memunculkan suatu bentuk konsekuensi logis tentang adanya proses pembentukan identitas diri masyarakat yang berdasarkan pada pola perubahan dan pola adaptasi. Pola perubahan dan pola adaptasi suatu masyarakat seringkali didorong oleh adanya suatu mekanisme sosial yang dikenal sebagai konflik sosial. Konflik sosial diartikan sebagai gambaran tentang perselisihan, percekcokan, ketegangan atau pertentangan sebagai akibat dari perbedaanperbedaan yang muncul dalam kehidupan masyarakat, baik perbedaan yang bersifat individual maupun perbedaan kelompok. ${ }^{9}$ Konflik sosial juga diartikan sebagai ketidaksepakatan yang tajam atau oposisi atas berbagai kepentingan, ide, dan lain-lain. Lebih lanjut konflik sosial berarti adanya suatu persepsi tentang perbedaan kepentingan (Perceived divergence of interest), atau munculnya kepercayaan bahwa setiap aspirasi individu yang berkonflik tidak dapat dicapai secara simultan. ${ }^{10}$ Dari definisi tersebut nampak suatu konsep dasar tentang kondisi konflik sosial yang bukan saja berhubungan dengan konfrontasi fisik melainkan juga berhubungan dengan perbedaan kepentingan,

${ }^{8}$ Nasokhili Giawa, "Kepemimpinan Nehemia Dan Relevansinya Dalam Pengelolaan Perguruan Tinggi Keagamaan Kristen Di Indonesia," Jurnal Ilmiah Religiosity Entity Humanity (JIREH) 1, no. 2 (2019): 149-160.

${ }^{9}$ Endar R. Chotim Irwandi, "Analisis Konflik Antara Masyarakat, Pemerintah Dan Swasta," JISPO 7, no. 2 (2017): 24-42.

${ }^{10}$ Dean G. dan Jeffrey Z. Rubin Pruitt, Teori Konflik Sosial (Yogyakarta: Pustaka Pelajar, 2009), 9-10. 
konsep maupun gagasan sehingga melahirkan pertentangan antara dua pihak atau lebih dalam berbagai aspek kehidupan masyarakat.

Konflik sosial merupakan dasar penting dalam pembentukan identitas suatu masyarakat. ${ }^{11}$ Hal ini menandai adanya suatu hubungan erat antara peristiwa konflik dengan perubahan sosial masyarakat yang cenderung menjadi rangkaian proses yang berkelanjutan. ${ }^{12}$ Akibatnya, setiap proses perubahan sosial pasti memiliki ikatan kedekatan yang bersifat adaptif dengan peristiwa konflik sosial.

Secara teoritis, konflik sosial merupakan salah satu hal fundamental dari perkembangan kehidupan manusia yang memiliki karakteristik heterogen. Kenyataan bahwa manusia merupakan makhluk heterogen tercermin jelas pada berbagai perbedaan yang muncul secara kasat mata, baik itu dalam hal perbedaan jenis kelamin, sistem hukum, strata ekonomi, sistem budaya, sistem kepercayaan, pandangan politik, dan sebagainya. Sifat heterogenitas itulah yang menyebabkan munculnya berbagai situasi berupa benturan sosial atau konflik sosial. Selama sifat dasar heterogenitas manusia masih ada, maka peristiwa konflik akan selalu menjadi hal yang tak terhindarkan dalam berbagai dimensi kehidupan manusia. Dengan dasar pandangan tersebut, maka setiap bentuk konflik sosial selalu memiliki dwifungsi perubahan sosial yakni dapat menjadi alat perekat sekaligus alat perenggang dalam sistem ikatan sosial masyarakat. Dalam hal inilah konflik sosial memiliki peranan strategis dalam menentukan pola dan bentuk perubahan sosial suatu masyarakat dari waktu ke waktu. ${ }^{13}$

Dilihat dari bentuk dan jenisnya, konflik sosial dapat tampil dalam berbagai wujud dan kriteria pada struktur masyarakat yang bersifat multikultural. Konflik sosial dapat dikelompokan berdasarkan altar terjadinya konflik, pihak yang terkait dalam konflik, substansi konflik, dan lain-lain. Berdasarkan dampaknya, konflik sosial dapat diklasifikasikan menjadi dua bentuk yakni konflik destruktif dan konstruktif. ${ }^{14}$ Dua jenis konflik tersebut merupakan motor pengerak yang penting bagi terjadinya suatu proses perubahan sosial masyarakat. Muncul dan berkembangnya berbagai ragam jenis konflik merupakan bentuk ekspresi sosial masyarakat yang sedang mengalami proses

${ }^{11}$ Lauer, Perspektif Tentang Perubahan Sosial, 287.

${ }^{12}$ Ibid., 290.

${ }^{13}$ Nitis Harsono, "Tugas Manusia Dalam Dunia Milik Tuhan," FIDEI: Jurnal Teologi Sistematika dan Praktika 3, no. 1 (2020): 110-125.

${ }^{14}$ Wirawan, Konflik Dan Manajemen Konflik: Teori, Aplikasi, Dan Penelitian (Jakarta: Salemba Humanika, 2010), 55-60. 
adaptasi sosial sehingga menghasilkan masyarakat yang bersifat adaptif terhadap perubahan sosial.

Kenyataan bahwa setiap masyarakat pasti memiliki struktur sosialnya masing-masing telah menimbulkan berbagai perbedaan dinamika sosial yang menyebabkan perubahan pola-pola perilaku sosial. Perubahan dan perkembangan masyarakat pada berbagai dimensi kehidupan sosial, merupakan hasil akhir dari proses interaksi sosial yang bersifat kompleks. Interaksi sosial adalah wujud perjumpaan individu-individu yang memunculkan berbagai perubahan termaksud karena adanya konflik sosial.

Konflik sosial sering kali merupakan bentuk letupan dari berbagai proses interaksi sosial yang disebabkan baik oleh faktor internal maupun eksternal suatu masyarakat. Terdapat banyak faktor yang menjadi pendorong terciptanya situasi konflik yang menimbulkan pergolakan dan perubahan masyarakat secara dinamis. Konflik sosial terjadi apabila norma sosial dalam keadaan lemah atau sedang mengalami perubahan. Pada saat-saat semacam itu orang akan cenderung membentuk suatu cara pandang yang bersifat idiosyncratic mengenai hak-hak sosial dan individunya. ${ }^{15}$

Cara pandang demikian akan melahirkan beberapa kondisi dasariah yang menjadi sebab atau alasan terjadinya konflik pada kerangka perubahan sosial masyarakat. Kondisi dasariah tersebut antara lain: (1) kondisi teknis, (2) kondisi politik, (3) dan kondisi sosial. ${ }^{16}$ Ketiga kondisi ini menjadi faktor pendorong terbentuknya konflik dalam proses interaksi sosial. Adanya keterhubungan dan tumpang tindih antara ketiga kondisi tersebut juga menunjukan adanya suatu proses tarik menarik yang kuat secara empiris antara peristiwa konflik dengan perubahan sosial pada tatanan riil masyarakat. Ketiga faktor tersebut terhubung secara dinamis pada tataran horizontal masyarakat disetiap proses sosialnya.

Jika dipahami secara mendalam, secara teoritis, kondisi teknis yang menyebabkan terjadinya konflik sebagai syarat terbentuknya perubahan sosial masyarakat adalah kondisi munculnya seorang pemimpin dan pembentukan ideologi pada tataran empiris. Kedua hal tersebut dianggap memainkan peranan stategis dalam pembentukan kelompok konflik dan tindakan kolektif yang penting bagi setiap perubahan sosial masyarakat. Hal ini disebabkan oleh karena tidak ada tindakan kelompok yang diorganisasi dapat terjadi tanpa suatu tipe kepemimpinan dan suatu bentuk kepercayaan yang bersifat membenarkan atau

${ }^{15}$ Pruitt, Teori Konflik Sosial, 32.

${ }^{16}$ Ralf Dahrendorf, Class and Class Conflict in Industrial Society (Stanford Calif: Stanford University Press, 1959), 182-189. 
ideologi. ${ }^{17}$

Dalam hal kondisi politik, hal penting yang ditekankan adalah adanya tingkat kebebasan pada individu untuk membentuk suatu komunitas dan tindakannya. Pada tingkat komunitas tertentu, kondisi ekstrim dapat diperlihatkan oleh adanya pemerintahan totaliter yang melarang terbentuknya partai politik oposisi atau model asosiasi sosial-politik lainnya. Sedangkan pada kutup berbeda, diperlihatkan adanya suatu komunitas masyarakat demokratis yang terbuka dan toleran terhadap macam-macam kelompok konflik untuk mengejar kepentingan dalam batas-batas pengaturan hukum yang luas demi melindungi kemerdekaan bagi semua orang. Variasi yang sama dapat pula kita amati dalam asosiasi-asosiasi tertentu. Dalam beberapa asosiasi, pembentukan kelompok konflik secara terang-terangan atau samar-samar dipersulit, kalau bukan dilarang, sedangkan dalam asosiasi yang lain, kelompok konflik itu diizikan atau diharapkan untuk dapat mempengaruhi proses pengambilan keputusan, paling kurang dalam batas-batas tertentu. ${ }^{18}$

Pada kategori kondisi sosial, hal yang paling ditekankan adalah tentang tingkat komunikasi antaranggota dari suatu kelompok tertentu. Kelompokkelompok konflik pasti tidak akan muncul diantara orang-orang yang terpisah dalam hal jarak dan tempat. Individu-individu yang terlibat konflik sosial tidak dibatasi oleh kondisi ekologis yang terpencar-pencar. Konflik sosial dapat terjadi hanya jika setiap individu dalam suatu komunitas memiliki tingkat komunikasi sosial yang buruk sehingga memunculkan adanya dinamika perubahan sosial suatu masyarakat. Pada titik ini, kualitas suatu komunikasi sosial akan sangat menentukan proses terjadinya konflik dan perubahan sosial masyarakat. ${ }^{19}$

Kondisi kebebasan politik, kondisi ideologi, kondisi kepemimpinan, dan kondisi komunikasi internal, merupakan prasyarat dasar untuk pembentukan kelompok-kelompok konflik. Jika satu dari elemen-elemen tersebut tidak terdapat diantara para anggota suatu kelompok, maka kelompok konflik tidak akan terbentuk. ${ }^{20}$ Selain kondisi-kondisi tersebut, perlu juga adanya prasyarat psikologis tertentu atau sosial psikologis. Salah satu prasyarat yang pokok adalah tentang keinginan laten yang menjadi manifest. Meskipun proses ini

${ }^{17}$ Ibid., 182-184.

${ }^{18}$ Ibid., 184-185.

${ }^{19}$ Ibid., 186-188.

${ }^{20}$ Doyle Paul Johnson, Teori Sosiologi: Klasik Dan Modern 2 (Jakarta: Gramedia Pustaka Utama, 1990), 187. 
dapat dirangsang oleh pimpinan kelompok konflik (ideologinya) dan pola komunikasinya, namun secara konseptual proses ini berbeda di tingkat psikologis individu yang lebih dari pada di tingkat struktural. ${ }^{21}$

Dari penjelasan tersebut, tergambar jelas adanya hubungan konseptual antara unsur-unsur internal dan eksternal dalam situasi konflik sosial sebagai faktor pendorong perubahan sosial suatu masyarakat. Kualitas hubungan antar individu pada suatu komunitas masyarakat, telah memainkan peran penting dan stategis dalam konteks hubungan antara konflik dengan perubahan sosial. Hal ini menandai adanya hubungan erat antara berbagai dimensi sosial yang terintegrasi dalam suatu komunitas masyarakat. Jika seluruh penjelasan diatas tervisualisasi secara simultan, maka akan nampak sebagai berikut:

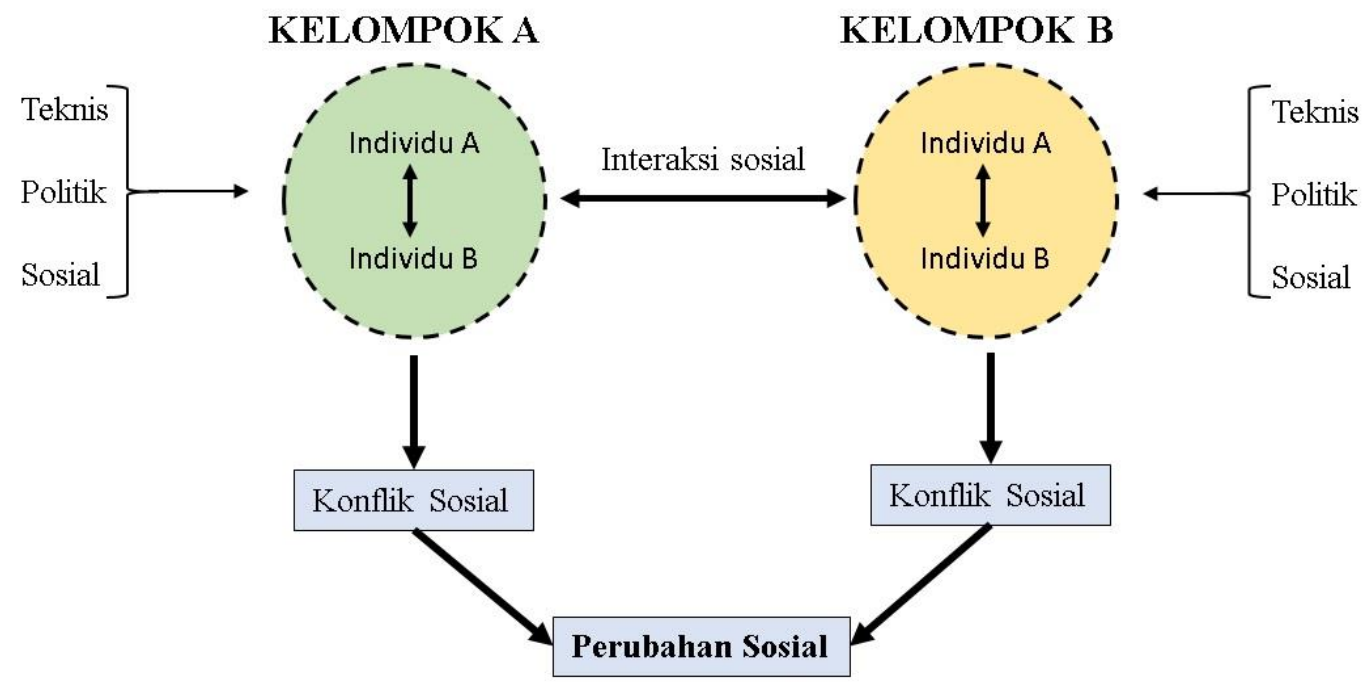

\section{Latar Belakang Sejarah 1 Raja-Raja 12 1-19}

Kitab Raja-raja merupakan kelanjutan sejarah yang tercatat dalam 1 dan 2 Samuel. Kitab-kitab ini secara selektif meliputi seluruh sejarah para raja Israel dan Yahuda. Kitab 1 dan 2 Raja-raja diperkirakan tertulis secara lengkap dalam dasawarsa 560-550 sM. Tujuan penulisan kitab ini adalah untuk menjelaskan peristiwa perpecahan kerajaan serta keruntuhan kerajaan Israel dan Yahuda. ${ }^{22}$ Kitab 1 dan 2 Raja-raja merupakan bagian panjang dari teks-teks Deuteronomis

${ }^{21}$ Ibid.

${ }^{22}$ Rahel R. dan Riana U .Sihombing Sarungallo, "Tinjauan Teologis Integritas Elia Berdasarkan 1 Raja-Raja 17: 1 - 19: 21,” Kerusso 4, no. 1 (2019): 26-33. 
(DH) dan merupakan kitab penutup sejarah Deuteronomis (DH). ${ }^{23}$ Teks-teks Deuteronomis adalah teks-teks yang dianggap memiliki hubungan erat dengan konteks pemerintahan raja-raja Israel pada periode waktu yang panjang, mulai dari masa sebelum pembuangan sampai pada masa pembuangan.

Sebagai bagian yang integral dari gulungan besar kitab Raja-raja, sejarah teks 1 Raja-raja 12:1-19 merupakan sejarah yang berhubungan erat dengan penulisan teks-teks Deuteronomis (DH). Dikatakan demikian, karena secara struktural teks 1 Raja-raja 12:1-19 berisikan keberlanjutan kisah tentang pola kepemimpinan dinasti Daud dan konflik yang terjadi pada masa kerajaan Israel Bersatu. Hal tersebut menjelaskan bahwa teks 1 Raja-raja 12:1-19 merupakan teks yang berisikan latar belakang sejarah tradisi Deuteronomis dalam hubungan dengan sejarah penguasa dan kerajaannya yang sangat penting bagi upaya pembentukan identitas kebangsaan Israel.

Menurut Frank Moore Cross, terdapat dua struktur dan komposisi dasar dari tradisi Deuteronomis (DH) yakni Dtr 1 dan Drt 2. Dtr 1 ditulis pada masa reformasi raja Yosia atau masa sebelum pembuangan (640-609 sM) dalam hubungan dengan upaya reformasinya. Dtr1 memiliki dua tema besar dalam tulisannya yakni pertama, tema tentang "dosa Yerobeam" (1 Raj. 13:34) dan kedua, tema tentang Daud sebagai hamba Allah dan Yerusalem sebagai kota pilihan Allah (1 Raj. 11: 12-13, 2 Raj. 8: 19). Sedangkan Dtr 2 memiliki tema tersendiri yang berhubungan dengan kondisi masa pembuangan sebagai dasar alasan spiritual terjadinya kejatuhan Yerusalem dan dinasti Daud. ${ }^{24}$ Dua tema ini mewarnai hampir seluruh later belakang sejarah penulisan teks-teks Deuteronomis (DH).

Secara teoritis, kedudukan historis dari 1 Raja-raja 12:1-19 berada pada posisi sebagai bagian yang integral dari alasan tentang terjadinya kehancuran Yerusalem atas ketidaktaatan pada kehendak Yahweh. Latar belakang historis ini menempatkan teks 1 Raja-raja 12:1-19 pada posisi yang strategis dalam hubungan dengan kondisi masa pembuangan. Tulisan ini menekankan adanya ketidakbenaran dan ketidakadilan pada pola pemerintahan raja-raja Yahuda yang menyebabkan terjadinya keruntuhan kerajaan Israel Bersatu sebagai akibat penghukuman Tuhan atas dinasti Daud. Kisah dalam 1 Raja-raja 12:1-19 berupaya untuk memberikan gambaran historis tentang alasan-alasan konseptual

${ }^{23}$ Admadi B. Dase, "Kontribusi Hermeneutis 1 Raja-Raja 21 Terhadap Konflik Agraria Di Indonesia," BIA': Jurnal Teologi dan Pendidikan Kristen Kontekstual 2, no. 1 (2019): 40-54. ${ }^{24}$ Marisa Lauterboom, "Pelacur Suci,” Jurnal Bina Darma XXV, no. 27 (2007): 209226. 
dibalik perpecahan dan kejatuhan kerajaan Israel Bersatu. Tema inilah yang hendak diangkat oleh sejarah Deuteronimis (DH) sebagai fondasi penting dalam penulisan teks 1 Raja-raja 12:1-19. Dengan demikian pemahaman historis terhadap 1 Raja-raja 12:1-19 harus dilihat dalam kerangka tema ini.

\section{Israel dan Konflik Sosial Dalam 1 Raja-raja 12:1-19}

Kisah tentang konflik sosial bangsa Israel yang tercatat dalam 1 Raja-raja 12:1-19, diawali dengan cerita sejarah pemerintahan raja Salomo sebagai pengganti Daud. Dalam TANAK, Salomo dikenal sebagi sosok yang berhikmat. Hikmat Salomo bukan sekadar kognitif, namun merambah hingga pada kehidupan praksis. ${ }^{25}$ Namun konsep spritualitas semacam ini akan terlihat jelas perbedaannya jika pola kepemimpinan Salomo ditelisik dari kisah 1 Raja-raja 12:1-19. Dalam catatan sejarah, pola kepemimpinan Salomo banyak didominasi dengan upaya untuk melakukan pembangunan secara masif pada segala lini kehidupan masyarakat dan negara. Hasrat pembangunan yang besar tersebut, telah mendorong Salomo untuk mengembangkan suatu pola pendekatan kekuasaan yang berbeda dengan Daud. Akibatnya terjadilah berbagai pemberontakan sebagai bentuk perlawanan atas ketidaksukaan orang Utara terhadap Salomo.

Perlawanan terhadap Salomo dan kekuasaannya dengan cepat mendapat dukungan dari negara-negara asing seperti Mesir dan Aram. Sosok-sosok pemimpin potensial yang memimpin perlawanan terhadap Salomo dan kekuasaannya, seperti keturunan budak dari orang Edom (atau mungkin orang Aram), dilindungi di Mesir sampai waktu yang tepat untuk melakukan pemberontakan. ${ }^{26}$ Salah satu contohnya adalah Yerobeam I. Pada masa pemerintaham Salomo, Yerobeam I yang merupakan mantan kepala atministrator kekuasaan Salomo di Efraim, melarikan diri ke Mesir dan mendapat perlindungan di sana bersama pemberontak lainnya sebagai akibat perlawanan terhadap kekuasaan Salomo. ${ }^{27}$

Kepemimpinan Salomo yang diduga bergaya otokratis, telah menimbulkan dampak negatif bagi terbentuknya ikatan solidaritas mekanis suku-suku di Palestina. Pola kepemimpinan demikian juga menimbulkan berbagai

\footnotetext{
${ }^{25}$ Harls Evan Rianto Siahaan, "Hikmat Sebagai Implikasi Pendidikan Kristen: Refleksi 1 Raja-Raja 3: 1-15," Dunamis: Jurnal Teologi dan Pendidikan Kristiani 1, no. 1 (2016): 15-30.

${ }^{26}$ Robert B. dan Mary P. Coote Coote, Kuasa, Politik Dan Proses Pembuatan Alkitab (Jakarta: BPK Gunung Mulia, 2001), 41.

27 Ibid., 50.
} 
kepincangan dalam segi kesejahtraan dan keadilan sosial bagi rakyatnya sendiri. Kepincangan-kepincangan tersebut disebabkan karena adanya tuntutan kebutuhan finansial yang besar untuk memenuhi pembiayaan logistik pembangunan dan gaya hidup mewah penguasa. Tuntutan kebutuhan finansial yang besar tersebut diduga harus diimbangi dengan kerja keras penduduk desa tanpa mendapatkan pendapatan atau upah yang seimbang. Menurut Norman K. Gottwald, kondisi diatas merupakan faktor tekanan sistem ekonomi dan politik yang menindas dari kebijakan-kebijakan sistem pemerintahan pada masa itu. ${ }^{28}$ Secara lebih terperinci, Robert B. Coote menyebutnya sebagai tindakan kerja rodi dan pemungutan pajak tinggi (pajak mencekik leher) pada masyarakat desa di Utara. ${ }^{29}$

Tindakan kerja rodi dan pemungutan pajak yang tinggi (pajak mencekik leher) terhadap kaum tani tersebut disebabkan karena adanya pertumbuhan pesat pada pusat kota-kota pemerintahan sehingga menjadi benteng-benteng kokoh yang megah. Begitu pesatnya proses pembangunan tersebut, sehingga pernah terdapat puluhan kota benteng di Israel. Selain program pembangunan kota-kota benteng, terdapat pula program pembangunan istana raja dan Bait Allah sebagai pusat kultus dengan jumlah dana dan pekerja yang sangat besar.

Menurut catatan sejarah, terdapat pula gudang-gudang besar yang dibangun dengan tinggi, yang terdiri dari deretan ruang penyimpanan yang panjang dan sempit dengan dinding tebal dan fondasi, telah ditemukan di Yerikho, Lakhis, Megido, Bet-Semes dan mungkin T. Jemmeh serta T. BeitMirsim. Untuk pertama kalinya Israel memiliki kota-kota dengan tempat-tempat suci yang menyertainya, tentara, istana, badan-badan pemerintahan dan lumbung-lumbung yang amat besar. Pada masa pemerintahan saat itu, seorang bernama Adoram memimpin kerja paksa untuk membangun kembali pertahanan kota-kota di sepanjang rute perdagangan yang melewati kerajaan. Kota-kota tersebut adalah Hazor, Magido, Gezer, Bet-Horon dan Baalath, bersama dengan Tamar di Arabah. Kota-kota tersebut diperlengkapi sebagai gudang penyimpanan bagi hasil bumi setempat dan pusat-pusat kandang kuda bagi pasukan kereta tempur yang beroperasi dari tempat itu. Gerbang kota berbilik

${ }^{28}$ Norman K. Gottwald, The Hebrew Bible: A Socio-Literary Introduction (Philadelphia: Fortress Press, 1987), 341.

${ }^{29}$ Robert B. Coote, In Defense of Revolution: The Elohist History (Minneapolis: Fortress Press, 1991) bab 5 dan 6. 
enam yang monumental di Hazar, Megido dan Gezer dibangun berdasarkan denah yang seragam. ${ }^{30}$

Untuk membangun istana dan Bait Allah, Salomo dan pemerintahannya diduga telah menghabiskan dana dan daya dalam jumlah yang besar. Kedua bangunan tersebut terbuat dari banyak hiasan kayu cedar dan sejenis cemara dengan ukiran yang sangat indah. Kedua bangunan tersebut juga dilapisi oleh banyak emas, perak dan perunggu sehingga meninggalkan kesan yang sangat mewah. ${ }^{31}$ Proses pembangunan ini membutuhkan kayu yang banyak dari Tirus dan sebagian besar emas dari Mesir yang mencapai lima ton. Istana raja sendiri dilapisi dengan dua ratus lempeng besar dan tiga ratus lempeng kecil emas murni. Akibatnya, Salomo harus mengirim ke Tirus sebanyak 100.000 gantang gandum dan satu juta galon minyak zaitun tiap tahun, baik pada masa hujan maupun tidak sebagai bayaran atas utang pembangunan tersebut. Salomo diduga juga telah menyerahkan dua puluh kota dan desa di Galilea kepada raja Hiram. Semua itu belumlah cukup untuk melunasi utang kepada Tirus. ${ }^{32}$

Saat istana dan Bait Allah selesai dibangun, makanan dalam jumlah yang sangat besar ditambah biaya pesta peresmian yang megah diduga harus ditanggung oleh penduduk desa. Menurut catatan Coote, saat peresmian bait Allah para imam menyembelih 22.000 lembu jantan dan 120.000 domba. Bait Allah yang baru itu berarti daging bagi tiap orang, untuk satu hari. Derita akibat tidak adanya lembu jantan untuk digunakan di desa-desa dan biaya yang lebih besar untuk mendapatkan lembu jantan guna menggarap tanah sesudah itu, sulit dibayangkan. ${ }^{33}$

Guna membangun benteng, istana, dan Bait Suci, para penguasa di istana Salomo telah mempekerjakan tenaga kerja yang terdiri dari 30.000 pria dan pemuda, 80.000 tukang batu dan 70.000 pemikul keranjang yang dilakukan secara paksa. Petugas yang mengawasi pekerja ini berjumlah 3.300 orang. Jumlah pekerja yang sedemikian banyaknya membutuhkan pasokan makanan dan material dalam jumlah yang besar. Pasokan makanan dan material tersebut berasal dari perbekalan negara atau mereka dipaksa membawa sendiri dari rumah. Sedangkan untuk jenis pekerjaan yang membutuhkan ketrampilan khusus, pihak istana telah menyewa pengrajin-pengrajin yang terampil dari

${ }^{30}$ Robert B. Coote, In Defense of Revolution: The Elohist History (Minneapolis: Fortress Press, 1991), 51-52.

${ }^{31}$ Ibid., 53.

${ }^{32}$ Ibid., 55-56.

${ }^{33}$ Ibid., 54. 
kota-kota pelabuhan di Fenesia. Hal ini menggambarkan dengan jelas adanya penggelontoran biaya dalam jumlah besar demi menyukseskan program pembangunan para penguasa. ${ }^{34}$

Penderitaan rakyat jelata juga bertambah dengan adanya pembebanan biaya untuk konsumsi para pejabat dan pegawai di Yerusalem yang tafsir berjumlah 1.700 orang dengan tambahan 4000 orang. ${ }^{35}$ Bahkan menurut catatan TANAK sendiri, tiap hari, para penguasa di Istana raja dan keluarga mereka mengkonsumsi tiga puluh karung tepung roti, enam puluh karung gandum, tiga puluh ekor lembu jantan, seratus domba, dicampur dengan kijang dan unggas, anggur serta minyak dalam jumlah yang tidak bisa dirincikan. ${ }^{36}$ Pembiayaan terhadap tingkat konsumsi yang tinggi tersebut diduga harus dipikul oleh masyarakat desa sebagai sumber pendapatan istana raja.

Perubahan besar yang terjadi di Palestina pada masa kekuasaan Salomo dengan adanya berbagai program pembangunan fisik yang masif, juga telah mendorong dibentuknya kekuatan militer kerajaan yang besar, lengkap dengan kuda dan keretanya serta pasukan-pasukan sewaan untuk menjaga keamanan negara yang semakin maju dari berbagai sisi. Demi mendukung pembentukan kekuatan militer yang besar tersebut, maka biaya yang harus dikeluarkan oleh istana raja juga sungguh mencengangkan. Kereta tempurnya masing-masing seharga 600 syikal; kuda yang terlatih 150 syikal. Tiap kereta membutuhkan tiga ekor kuda, maka kereta beserta perangkat kudanya mencapai 1050 syikal. Kemudian, masih ada lagi biaya tambahan: awak kereta, petugas perawatan, senjata, suku cadang, perumahan bagi pegawai, tempat penginapan dan bengkel reparasi, kandang kuda dan pakan kuda. Pembongkaran dan pelumasan dengan minyak zaitun perlu sering dilakukan. Kuda-kuda membutuhkan latihan selama berbulan-bulan, kemudian latihan dan perawatan kuda secara terus-menerus oleh tenaga-tenaga terlatih. Kereta tempur Salomo berjumlah 1.400, kuda 4.000, awak kereta dan tenaga pendukung sampai 12.000 orang - seluruhnya bergantung pada bahan pangan yang ditanam oleh masyarakat desa. ${ }^{37}$ Jadi untuk kekuatan militer saja pihak istana harus mengeluarkan biaya yang sangat besar. Pembiayaan tersebut sepenuhnya diduga bergantung pada hasil produksi pertanian yang didapatkan dari kerja keras masyarakat desa di Utara.

\footnotetext{
${ }^{34}$ Ibid., 52.

${ }^{35}$ Ibid., 53.

${ }^{36}$ Coote, Kuasa, Politik Dan Proses Pembuatan Alkitab, 41-42.

${ }^{37}$ Coote, In Defense of Revolution: The Elohist History, 52.
} 
Tekanan sosial-ekonomi yang diakibatkan oleh adanya program pembangunan fisik dan kekuatan militer dalam skala masif tersebut, diduga pada akhirnya telah memunculkan berbagai reaksi perlawanan terhadap ketidakadilan dan kesewenang-wenangan penguasa atas rakyatnya sendiri. Reaksi perlawanan sporadis dari kaum tertindas terhadap Istana raja, diduga berlangsung selama masa pemerintahan Salomo sampai pada masa pemerintahan Rehabeam. Mereka melakukan perlawanan gerakan bawah tanah yang menentang perubahanperubahan yang menindas kaum tani dan rakyat jelata. Kaum ini dikenal dengan nama kaum Rekhabi. Namun tindakan perlawanan dari kaum Rekhabi tersebut selalu dianggap sebagai gerakan kaum pemberontak oleh para penguasa resmi sehingga mereka harus mengalami berbagai diskriminasi dan penindasan. ${ }^{38}$

Munculnya berbagai peristiwa pemberontakan sebagai embrio perpecahan kerajaan Israel Bersatu yang dimotori oleh kaum Rekhabi selama masa pemerintahan Salomo, menemukan puncak momentumnya pada peristiwa yang tercatat dalam 1 Raja-raja 12:1-19. Beban besar yang dipikul oleh masyarakat Utara sebagai konsekuensi logis dari hasrat besar Istana raja dalam program pembangunan fisik dan manusia, telah mendorong adanya kualisi masyarakat Utara yang dipimpin oleh Yerobeam I untuk melakukan protes diplomasi dan keberatan mendalam terhadap penerus tahta Salomo yakni raja Rehabeam saat berkunjung ke Sikhem. Protes tersebut tersimpulkan dalam narasa kalimat 1 Raja-raja 12:4, "ayahmu telah memberatkan tanggunan kami, maka sekarang ringankanlah pekerjaan yang sukar yang dibebankan ayahmu dan tanggungan yang berat yang dipikulkannya kepada kami, supaya kami menjadi hambamu".

Protes diplomasi koalisi rakyat Utara yang dipimpin oleh Yerobeam I terhadap ketidakadilan dan berbagai bentuk eksploitasi yang dialami semasa pergolakan politik dan proses pembangunan yang masif, ditanggap dingin oleh raja Rehabeam dengan perkataan, "Ayahku telah memberatkan tanggungan kamu, tetepi aku akan menambahkan tanggunganmu itu; ayahku telah menghajar kamu dengan cambuk, tetapi aku akan menghajar kamu dengan cambuk yang berduri besi" (1 Raj. 12:14). ${ }^{39}$ Tanggapan yang kurang bersahabat ini, telah memunculkan reaksi kemarahan koalisi rakyat Utara terhadap pola kepemimpinan dinasti Daud dengan menciptakan situasi konflik yang bersifat destruktif. Tindaklanjut kemarahan kualisi rakyat Utara ditunjukan dengan adanya upaya pengusiran paksa yang dilakukan terhadap Rehabeam dalam kisah

${ }^{38}$ Th. C. Vriezen, Agama Isarel Kuno (Jakarta: BPK Gunung Mulia, 2003), 194.

39 Christian Gossweiler, "Kepemimpinan Karismatik Dan Kepemimpinan Yang Melembaga Pada Masa Perjanjian Lama Dan Dewasa Ini," Jurnal Abdiel 3, no. 2 (2019): 25-32. 
1 Raja-raja 12:18. Protes diplomasi yang seharusnya berakhir dengan proses penyelesaian konflik secara kompromistis, akomonatif dan kolaboratif (win and win solution) berubah menjadi konflik destruktif yang menghasilkan perpecahan kerajaan sebagai akibat egosentrime penguasa (win and lose solution).

Kisah 1 Raja-raja 12:1-19 menggambarkan suatu proses konflik sosial yang disebabkan oleh adanya berbagai ketimpangan sosial dan ketidakadilan penguasa terhadap penderitaan rakyatnya. Peristiwa konflik yang terjadi di Israel adalah konflik yang telah melibatkan adanya tiga unsur penting sebagai bentuk akhir dari akumulasi berbagai faktor yang terjadi secara masif dalam konteks masyarakat Utara. Tiga faktor tersebut yakni: pertama, faktor politik yang berhubungan langsung dengan pola kepemimpinan penguasa yang diduga cenderung mengutamakan kepentingan politik dan keuntungan ekonomi dibandingkan kesejahtraan rakyatnya sendiri. Kondisi ini nampak jelas dalam situasi ekploitasi dan ketidakadilan sosial yang dialami oleh suku-suku di Utara seperti yang tercatat dalam kisah 1 Raja-raja 12:1-19. Kedua, faktor teknis dimana terdapat seorang pemimpin dikalangan rakyat Utara yang berani tampil dalam membela dan mendorong terjadinya perubahan sosial dikalangan rakyat Utara. Yerobeam I yang telah mendapat dukungan dari berbagai pihak di Utara akhirnya tampil sebagai sosok pemimpin karismatik yang berkontribusi penting bagi terwujudnya revolusi Utara. Dukungan terhadap Yerobeam I tersebut, besar manfaatnya bagi pembentukan legalitas kepemimpinan dan loyalitas kesukuan. Kondisi tersebut disebabkan karena dalam tradisi suku-suku di Palestina seorang imam atau hakim (local Hero) adalah pemimpin utama yang memiliki otoritas dan kekuasaan melindungi anggota sukunya. ${ }^{40}$ Karenanya, mendapat dukungan dari tokoh-tokoh penting di Utara adalah besar pengaruhnya bagi eksistesi kepemimpin seorang Yerobeam I. Ketiga, faktor sosial dimana terjadinya suatu ketimpangan dan ketidakadilan sosial yang diduga telah menyebabkan penderitaan fisik dan mental bagi penduduk Utara sebagai akibat terjadinya berbagai tindakan esploitasi dan diskriminasi. Ketimpangan-ketimpangan sosial yang terjadi saat itu, pada akhirnya menjadi faktor utama pendorong dan pencetus terjadinya puncak konflik sosial yang bersifat destruktif antara penguasa di Selatan dengan rakyat Utara dalam kisah 1 Raja-raja 12:1-19.

${ }^{40}$ Agnes M. Takaendengan, "Analisis Sosio-Historis Terhadap Narasi Kebangsaan Tradisi Yahwisme Menurut Nasionalisme Modern,” Jurnal Hibualamo 2, no. 1 (2018): 45-57. 


\section{Relevansi Kekinian Kisah Konflik 1 Raja-Raja 12:1-19}

Konflik sosial merupakan hal mendasar dalam setiap proses perubahan masyarakat. Secara teoritis, konflik sosial memainkan peran penting dalam mendukung terbentuknya pola pergerakan masyarakat dinamis. Konflik sosial perlu dimaknai sebagai suatu jalan atau sarana menuju perubahan masyarakat. ${ }^{41}$ Konflik sosial yang terjadi pada masyarakat dapat menghasilkan suatu model konstruksi interaksi sosial yang bersifat unik. Konflik sosial dapat menghasilkan pergerakan sosial yang mendukung munculnya kemajuan suatu masyarakat, tetapi juga dapat menghasilkan ketidaksabilan sosial bahkan perpecahan dalam hubungan horizontal masyarakat.

Dilihat dari konstruksi historis kisah 1 Raja-raja 12:1-19, terlihat jelas adanya hubungan erat antara peristiwa konflik sosial dengan perpecahan kerajaan Israel Bersatu yang terjadi pada tahun 931/930 sM. Perpecahan kerajaan Israel Bersatu merupakan hasil dari suatu konflik panjang antara penguasa dinasti Daud dengan suku-suku di Utara. Peristiwa perpecahan kerajaan tersebut diduga merupakan hasil akumulasi dari berbagai faktor pendorong konflik seperti penindasan, kesewenang-wenangan, eksploitasi dan ketidakadilan sosial yang terjadi pada rakyat Israel Utara.

Melihat dan memahami faktor-faktor pendorong perpecahan kerajaan Israel Bersatu seperti yang dicatat dalam kisah 1 Raja-raja 12:1-19, telah memunculkan pengertian mendasar bahwa setiap perlakuan yang bermuatan tindakan ketidakadilan sosial, penindasan, dan ekploitasi oleh penguasa terhadap rakyatnya akan berujung kepada tindakan pemberontakan, konflik dan perpecahan sosial masyarakat. Tindakan pemberontakan, konflik, dan perpecahan seperti yang tercermin dalam kisah 1 Raja-raja 12:1-19 merupakan bentuk konsekuensi logis dari proses komunikasi sosial yang buruk. Pemutusan komunikasi sosial dan adanya sistem pemerintahan yang bersifat otoritarianisme, telah menjadi akar persoalan terjadinya konflik karena ketidakadilan, penindasan dan eksploitasi yang terjadi secara terus-menerus terhadap rakyat kecil.

Belajar dari kisah terjadinya konflik sosial di Israel seperti yang tercatat dalam kisah 1 Raja-raja 12:1-19, memunculkan suatu ide tentang konsep penanganan konflik yang lebih adaptif dan ideal dalam konteks dinamika perubahan masyarakat modern saat ini. Jika konflik dipahami sebagai situasi

${ }^{41}$ Sukardi, "Penanganan Konflik Sosial Dengan Pendekatan Keadilan Restoratif," Jurnal Hukum \& Pembangunan 46, no. 1 (2016): 70-89. 
yang wajar dalam proses perubahan sosial, maka yang terpenting dari penanganan konflik sosial agar tidak menimbulkan sifat yang destruktif bagi masyarakat adalah pola pengelolaan konflik dan komunikasi sosial.

Pola pengelolaan konflik dan komunikasi sosial dalam konteks masyarakat majemuk saat ini, harus didasarkan kepada hubungan komunikasi yang bersifat egaliter dan manejeman konflik yang bersifat restitutif. Hal ini berarti komunikasi antara pihak penguasa dan rakyat yang dipimpinnya harus berjalan dalam koridor hukum dan etika sosial. Setiap penguasa maupun rakyat yang dipimpinnya harus secara sadar mematuhi setiap unsur hukum positif yang berlaku secara lagal pada suatu negara sambil mengedepankan komitmen dalam menjunjung tinggi nilai-nilai Hak Asasi Manusia sebagai dasar penting dalam setiap proses penegakan hukum. Sedangkan dalam upaya mewujudkan suatu manejeman konflik yang bersifat restitutif, maka segala bentuk pengelolaan konflik harus berujung kepada upaya menciptakan kondisi konflik yang bersifat win and win solution, yang berarti suatu kondisi dimana pihak-pihak yang berkonflik harus berupaya menciptakan proses dialog yang mengedepankan sikap menjunjung tinggi nilai-nilai perdamaian dan rekonsiliasi sebagai modal dasar kesatuan masyarakat. Dengan penerapan dua metode tersebut (komunikasi yang bersifat egaliter dan manajemen konflik yang bersifat restitutif), maka setiap peristiwa konflik yang terjadi pada konteks masyarakat modern dapat tertata secara baik sehingga menghasilkan keluaran konflik yang bersifat konstruktif bagi hubungan sosial antara individu dalam konteks masyarakat luas.

Kondisi masyarakat modern yang terbuka dan egalitar sebagai akibat dari kemajuan pendidikan dan teknologi, juga tidak dapat terlepas dari fenomena sosial berupa peristiwa konflik yang disebabkan oleh adanya ketidakadilan sosial, eksploitasi, kesewenang-wenangan dan penindasan. Berbagai contoh nyata peristiwa ketidakadilan sosial dan tindakan eksploitasi yang masih terjadi pada masyarakat modern seperti pelanggaran Hak Asasi Manusia, Human Trafficking (perbudakan modern), kerja paksa dengan upah kerja yang rendah, pembungkaman hak-hak demokrasi (lihat peristiwa sosial demokrasi di negara Korea Utara saat ini), diskriminasi etinis dan ras, diskriminasi golongan dan agama, kesenjangan ekonomi antara masyarakat sampai persoalan ekploitasi sistem keuangan (pemberian utang dengan bunga yang tinggi oleh individu atau lembanga keuangan tertentu), masih terus menjadi sumber konflik sosial masyarakat yang terikat secara organik. Hal ini menandakan adanya berbagai bentuk degradasi sosial yang berujung kepada peristiwa konflik dan perpecahan masyarakat masa kini. 
Berdasarkan kenyataan tersebut, perlu adanya perhatian serius dari berbagai komponen sosial masyarakat dalam hal mencari dan mengupayakan bentuk-bentuk penanganan konflik sosial yang bersifat adaptif terhadap kemajuan, kesejahtraan sosial dan kemajemukan. Berbeda dengan model resolusi konflik di Israel seperti yang tercatat dalam 1 Raja-raja 12:1-19, resolusi konflik pada konteks masyarakat modern yang serba majemuk harus meninggalkan pola-pola penanganan konflik yang bersifat win and lose solution. Penanganan konflik masyarakat modern harus mengutamakan pendekatan sosial yang berbentuk kompromi, kolaborasi dan penegakan hukum yang bersifat restitutif dalam menciptakan suatu keluaran konflik yang konstruktif bagi kemajuan masyarakat. Pada akhirnya, konsep di atas akan mendorong terwujudnya prinsip-prinsip kesejahtraan bersama, keadilan, kemanusiaan dan kesamaderajatan bagi seluruh warga masyarakat. ${ }^{42}$ Tanpa pengelolaan yang demikian, maka peristiwa konflik sosial yang terjadi pada konteks masyarakat modern akan berakhir dengan kondisi win and lose solution (ikhtiar untuk mengalahkan lawan konflik) seperti dalam kisah 1 Raja-raja 12:1-19.

\section{Simpulan}

Dari keseluruhan penjelasan di atas dapat disimpulkan bahwa peristiwa konflik sosial yang terjadi pada kisah 1 Raja-raja 12:1-19 adalah suatu puncak peristiwa konflik yang diduga disebabkan oleh munculnya berbagai bentuk tindakan ekploitasi, penindasan dan diskriminasi para penguasa terhadap rakyatnya sendiri. Hal tersebut telah mengakibatkan adanya berbagai ketimpangan sosial, ketidakadilan sosial dan kesewenang-wenangan yang berujung kepada revolusi sosial sebagai tingkat terekstrim dari peristiwa konflik sosial. Peristiwa konflik sosial seperti yang tercatat dalam 1 raja-raja 12:1-19 juga memberikan pembelajaran sosial terbaik dalam hal penanganan konflik yang harus dilakukan dalam konteks masyarakat modern. Tindakan penanganan konflik tersebut harus mencakup dua hal penting yakni pertama, upaya preventif konflik berupa komunikasi yang bersifat egaliter dan kedua, manajemen konflik yang bersifat restitutif (win and win solution).

${ }^{42}$ Firman Panjaitan, "Kekerasan Terhadap Istri Dalam Lingkup Domestik (Suatu Tinjauan Etis Kristiani Tentang Kekerasan Terhadap Keluarga)," Fidei: Jurnal Teologi Sistematika dan Praktika 1, no. 1 (2018): 42-67. 


\section{Daftar Pustaka}

Coote, Robert B.; Mary P. Coote. Kuasa, Politik Dan Proses Pembuatan Alkitab. Jakarta: BPK Gunung Mulia, 2001.

Coote, Robert B. In Defense of Revolution: The Elohist History. Minneapolis: Fortress Press, 1991.

Dahrendorf, Ralf. Class and Class Conflict in Industrial Society. Stanford Calif: Stanford University Press, 1959.

Dase, Admadi B. "Kontribusi Hermeneutis 1 Raja-Raja 21 Terhadap Konflik Agraria Di Indonesia." BIA': Jurnal Teologi dan Pendidikan Kristen Kontekstual 2, no. 1 (2019).

Giawa, Nasokhili. "Kepemimpinan Nehemia Dan Relevansinya Dalam Pengelolaan Perguruan Tinggi Keagamaan Kristen Di Indonesia.” Jurnal Ilmiah Religiosity Entity Humanity (JIREH) 1, no. 2 (2019).

Gossweiler, Christian. "Kepemimpinan Karismatik Dan Kepemimpinan Yang Melembaga Pada Masa Perjanjian Lama Dan Dewasa Ini." Jurnal Abdiel 3, no. 2 (2019).

Gottwald, Norman K. The Hebrew Bible: A Socio-Literary Introduction. Philadelphia: Fortress Press, 1987.

- The Politics of Ancient Israel. Louisville-Kentucky: Westminster John Press, 2001.

Harsono, Nitis. "Tugas Manusia Dalam Dunia Milik Tuhan.” FIDEI: Jurnal Teologi Sistematika dan Praktika 3, no. 1 (2020).

Irwandi, Endar R. Chotim. "Analisis Konflik Antara Masyarakat, Pemerintah Dan Swasta." JISPO 7, no. 2 (2017).

Johnson, Doyle Paul. Teori Sosiologi: Klasik Dan Modern 2. Jakarta: Gramedia Pustaka Utama, 1990.

Koenig, Samuel. Mand and Society, the Basic Teaching of Sociology. New York: Barners \& Noble Inc, 1957.

Lauer, Roberth H. Perspektif Tentang Perubahan Sosial. Jakarta: PT Rineka Cipta, 2001.

Lauterboom, Marisa. "Pelacur Suci." Jurnal Bina Darma XXV, no. 27 (2007).

Mustamin. "Studi Konflik Sosial Di Desa Bugis Dan Parangina Kecamatan Sape Kabupaten Bima Tahun 2014.” Jurnal Ilmiah Mandala Education 2, no. 2 (2016).

Panjaitan, Firman. "Kekerasan Terhadap Istri Dalam Lingkup Domestik (Suatu Tinjauan Etis Kristiani Tentang Kekerasan Terhadap Keluarga)." Fidei: Jurnal Teologi Sistematika dan Praktika 1, no. 1 (2018). 
Pruitt, Dean G.; Jeffrey Z. Rubin. Teori Konflik Sosial. Yogyakarta: Pustaka Pelajar, 2009.

Sarungallo, Rahel R. dan Riana U .Sihombing. "Tinjauan Teologis Integritas Elia Berdasarkan 1 Raja-Raja 17: 1 - 19: 21.” Kerusso 4, no. 1 (2019).

Siahaan, Harls Evan Rianto. "Hikmat Sebagai Implikasi Pendidikan Kristen: Refleksi 1 Raja-Raja 3: 1-15.” DUNAMIS: Jurnal Teologi dan Pendidikan Kristiani 1, no. 1 (2016).

Sukardi. "Penanganan Konflik Sosial Dengan Pendekatan Keadilan Restoratif." Jurnal Hukum \& Pembangunan 46, no. 1 (2016).

Syas, Mulharnetti. "Konstruksi Realitas Pemberitaan Tentang Konflik Indonesia-Malaysia Di Surat Kabar Media Indonesia." Jurnal Ilmu Komunikasi 13, no. 2 (2015).

Takaendengan, Agnes M. "Analisis Sosio-Historis Terhadap Narasi Kebangsaan Tradisi Yahwisme Menurut Nasionalisme Modern.” Jurnal Hibualamo 2, no. 1 (2018).

Wirawan. Konflik Dan Manajemen Konflik: Teori, Aplikasi, Dan Penelitian. Jakarta: Salemba Humanika, 2010. 